\title{
The Use of Harmonic Scalpel in Subtotal Thyroidectomy: Single Centre Experience
}

\author{
MOHAMMED M. EL-SHAFIE, M.D.; SAMIR A. AMMAR, M.D. and AL-HASSAN M. ALI, M.Sc. \\ The Department of General Surgery, Faculty of Medicine, Assiut University, Assiut, Egypt
}

\begin{abstract}
Background: In conventional subtotal thyroidectomy, the use of clamp and tie technique combined with electrocautery consumes longer time and can cause much blood loss and recurrent laryngeal nerve damage.

Patients and Methods: Our study included 40 patients scheduled for open subtotal thyroidectomy and were divided into two groups each contain 20 patient, the first group undrewent subtotal thyroidectomy using the traditional clamp and tie technique and the second group using the Harmonic Focus Scalpel, then we compared between the two groups concerning operative time, post-operative pain, RLN injury, seroma and wound infection, hypothyroidism and hospital stay.

Results: The mean operative time for group 1 was $(147.25 \pm$ $25.88)$ and $(125.75 \pm 20.34)$ for group 2 with the $p$-value (0.008). The mean post-operative drainage volume (in CC) was (24.75 \pm 4.69$)$ for group 1 and $(18.60 \pm 4.02)$ for group 2 with $p$-value (0.001).

Other post-operative complications (RLN damage, pain, hypocalcaemia, haematoma) in both groups were statistically insignificant. Post-operative hospital stay was the same for both groups.

Conclusion: In our results we founded that the operative time has been decreased, also the post-operative drainage volume has been decreased in group two where we used the Harmonic Focus Scalpel. Post-operative pain and other complications like recurrent laryngeal nerve injury or hypocalcaemia were the same in both groups. Days of hospitalization were the same in both groups. According to our experience in Assiut University Hospital the use of Harmonic Focus Scalpel is safe and effective during open subtotal thyroidectomy and can improve the surgical outcome.
\end{abstract}

Key Words: Harmonic scalpel - Subtotal thyroidectomy.

\section{Introduction}

THYROID surgery initially started in 12 th century with the use of setors, hot irons. A major advance

Correspondence to: Dr. Al-Hassan M. Ali, E-Mail: Alhassan.mamdouh@yahoo.com was the introduction of ether anaesthesia, antisepsis and artery forceps to the practice. The pioneers of thyroid surgery Kocher and Billroth, developed an acceptable technique of standardized thyroid surgery between the years 1873 and 1883. By 1920, the principles of safe thyroid surgery have been established [1].

Traditional thyroid surgery depends on ligation or diathermy. The technique of thyroidectomy has undergone little change in several decades. Recently, there are a reports about the use of the harmonic scalpel in thyroidectomy [2].

The harmonic scalpel is an instrument that uses ultrasonic technology to make incisions with minimal collateral tissue damage. The device vibrate at more than 55,000 times per second to cut tissue and to seal blood vessels [3]. Laparoscopists were the first to use the method widely. It has proven to decrease operation time and complications [4] The harmonic scalpel, using ultrasonic frictional heating to ligate vessels, is widely used in laparoscopic surgery, but there is little experience in open thyroidectomy. The use of harmonic scalpel in thyroid surgery offers several advantages over the conventional technique. The incision is shorter and operating time is reduced. Bleeding is negligible and complications are few. The harmonic scalpel offers the thyroid surgeon the ability to control the feeding vessels through a limited field safely $[\mathbf{5 , 6}]$.

\footnotetext{
Abbreviations:

HS : Harmonic Scalpel.

CT : Conventional Thyroidectomy.

VAS : Visual Analogue Scale.

RLN : Recurrent Laryngeal Nerve.

MNG : Multinodular Goiter.
} 


\section{Patients and Methods}

Patients: This prospective study included 40 patients who were admitted to Assiut University Hospital in the periode from April 2016 till January 2017, all the patients had been presented with different thyroid pathologies and scheduled for open subtotal thyroidectomy including:

- Simple multinodular goiter.

- Diffuse toxic goiter relapsing after medical treatment.

- Secondary toxic goiter.

- Selected cases of thyroiditis.

\section{Exclusion criteria were:}

- Unfit patients with severe comorbidities or coagulation disorders or not willing for surgery.

- Previous neck surgery or irradiation.

- Concomitant parathyroid disorders.

- Thyroid carcinoma.

All the 40 eligible patients were operated upon by the same team of surgeons and they were randomly categorized into two groups, group one comprised 20 patients who underwent subtotal thyroidectomy using conventional suture ligation or clamp and tie technique and group two comprised 20 patients who underwent subtotal thyroidectomy using the Harmonic focus Scalpel. The study and the procedure were explained to all patients preoperatively. Local ethics committee approval and pre-operative informed consent from all patients were obtained.

Methods: All the patients had been subjected to the following:

\section{1- Pre-operative assessment:}

- Full clinical assessment.

- Routine laboratory studies.

- Thyroid profile.

- Neck ultrasonography; for detection of gland consistency, retrosternal extension, tracheal deviation, and cervical lymphadenopathy.

- Thyroid scan when indicated; was done for detection of the nature of the nodules (hotwarm-cold).

- Fine Needle Aspiration Cytology (FNAC); when indicated (cold nodule on thyroid scan or dominant one of multi nodular goitre or solitary thyroid nodule).
- Referral to ENT specialist; for indirect laryngoscopy to determine the mobility of the vocal folds.

All the patients were informed that they have to take post-operative medications (hormonal replacement). All patients were informed about all possible complications of subtotal thyroidectomy.

2- Operative technique: Standard subtotal thyroidectomy was performed for all patients. The monopolar electrocautary system was used as an accessory method for some small vessels, 1 to $2 \mathrm{~mm}$ in diameter, in both groups. With the patient under general endotracheal anaesthesia and the head of the patient in a mild dorsal extension and an anti-Trendelenburg position, a standard collar skin incision was made 2 to $3 \mathrm{~cm}$ above the sternal notch and the clavicles. The subcutaneous tissue and the platysma muscle were divided, the upper and lower subplatysmal flaps were developed by monopolar electrocautery in group 1 , or the harmonic scalpel in group 2. The strap muscles were divided in the midline and retracted laterally until the thyroid gland was exposed. It was rarely necessary to divide the strap muscles for better exposure, which also can be done using the Harmonic scalpel. The dissection began with sealing the branches of the middle thyroid vien using, clamp and tie technique in group 1 and the Harmonic scalpel in group 2. Gentle upward and medial retraction expose the vessels which can be grasped by the jaws of the Harmonic scalpel and when the energy-delivering period was over the Harmonic scalpel was withdrawn leaving sealed and cut tissue. Consecutively, the vessels of the superior pole were identified and sealed with the clamp and tie technique or the Harmonic scalpel. This area was carefully dissected to avoid injury to the superior laryngeal nerve. Dissection then continued on the lateral part of this lobe, and the small fibrovascular attachments were ligated with the clamp and tie technique or the Harmonic scalpel as they entered the thyroid capsule. The inferior pole of this lobe was then dissected free and ligation of the inferior pole vessels was performed with the clamp and tie technique in group 1, and the Harmonic scalpel in group 2 . The recurrent laryngeal nerves were always identified, and care was taken to avoid injury or trauma to the nerves while mobilizing the thyroid from the lateral and anterior parts of the trachea. An attempt was made to identify the all four parathyroid glands. Once they were identified, efforts were made to preserve the glands and their blood supply. After this lobe of the thyroid gland was dissected free to approximately the isthmus, attention was directed to the other side 
of the gland. The same technique was used for the resection of the contralateral lobe of the gland. The dissection was completed by mobilization of the isthmus and the pyramidal lobe. At the completion of subtotal thyroidectomy, the operative field was irrigated with normal saline and a small closed suction drain was inserted and was removed after 48 hours. The strap muscles were then drawn together with interrupted absorbable sutures; the platysma and the subcutaneous tissue were sutured with interrupted absorbable sutures and the skin closure was done with non-absorbable subcuticular or simple sutures. Operative time was calculated from the start of skin incision to the final suture in skin closure.

3-Post-operative assessment: During the postoperative period all patients were carefully assessed for the clinical symptoms and signs of complications especially:

- Pain: Post-operative pain was assessed for the first 2 post-operative days using the Visual Analogue Scale (VAS). The chart was graded from 0 to 10 , marked at one end as no pain and at the other end as the worst imaginable pain. Patient with scores 3 or less were defined as having mild pain, those with score 7 or more were considered to have severe pain and those between 3 and 7 were considered moderate pain. Marking the number was done according to our evaluation of patient description of pain and the analgesics required.

- Hypoparathyroidism: Diagnosed by symptoms and signs of hypocalcaemia including numbness, parasthesia and positive Chvostek sign and confirmation by an assay of serum calcium and phosphorus.

- Recurrent laryngeal nerve injury: Was checked by routine inspection of vocal folds during recovery from anaesthesia or indirect laryngoscopy in case of voice abnormalities, dyspnea or stridor post-operatively.

- Post-operative bleeding: Assessed through the drain.

- Seroma and wound infection.

- Hospital stay.

\section{Results}

Table (1): Mean age of the studied groups.

\begin{tabular}{llll}
\hline Age (years) & $\begin{array}{c}\text { Group I } \\
(\mathrm{n}=20)\end{array}$ & $\begin{array}{c}\text { Group II } \\
(\mathrm{n}=20)\end{array}$ & $p$-value \\
\hline Mean \pm SD & $34.25 \pm 9.75$ & $34.55 \pm 9.84$ & 0.946 \\
Range & $18.0-53.0$ & $20.0 \pm 52.0$ & \\
\hline
\end{tabular}

Table (2): Sex distribution of the studied groups.

\begin{tabular}{llclllll}
\hline \multirow{2}{*}{ Sex } & \multicolumn{2}{c}{ Group I $(\mathrm{n}=20)$} & & \multicolumn{2}{c}{ Group II $(\mathrm{n}=20)$} & \\
\cline { 2 - 3 } & No. & $\%$ & & No. & $\%$ & $p$-value \\
\hline Male & 3 & 15.0 & & 2 & 10.0 & 0.633 \\
Female & 17 & 85.0 & 18 & 90.0 & \\
\hline
\end{tabular}

Table (3): Mean operative time in the studied groups.

\begin{tabular}{llll}
\hline $\begin{array}{l}\text { Operative time } \\
\text { (minutes })\end{array}$ & \multicolumn{1}{c}{$\begin{array}{c}\text { Group I } \\
(\mathrm{n}=20)\end{array}$} & \multicolumn{1}{c}{$\begin{array}{c}\text { Group II } \\
(\mathrm{n}=20)\end{array}$} & $p$-value \\
\hline Mean \pm SD & $147.25 \pm 25.88$ & $125.75 \pm 20.34$ & $0.008^{*}$ \\
Range & $100.0-195.0$ & $100.0-180.0$ & \\
\hline
\end{tabular}

Table (4): Post-operative pain in the studied groups.

\begin{tabular}{|c|c|c|c|c|c|}
\hline \multirow{2}{*}{$\begin{array}{l}\text { Post-operative } \\
\text { pain }\end{array}$} & \multicolumn{2}{|c|}{ Group I $(n=20)$} & \multicolumn{2}{|c|}{ Group II (n=20) } & \multirow{2}{*}{$p$-value } \\
\hline & No. & $\%$ & Jo. & $\%$ & \\
\hline Mild & 9 & 45.0 & 11 & 55.0 & 0.527 \\
\hline Moderate & 11 & 55.0 & 9 & 45.0 & \\
\hline
\end{tabular}

Table (5): Drainage volume (CC) in the studied groups.

\begin{tabular}{lccc}
\hline $\begin{array}{l}\text { Drainage } \\
\text { volume }(\mathrm{CC})\end{array}$ & $\begin{array}{c}\text { Group I } \\
(\mathrm{n}=20)\end{array}$ & $\begin{array}{c}\text { Group II } \\
(\mathrm{n}=20)\end{array}$ & $p$-value \\
\hline Mean \pm SD & $24.75 \pm 4.69$ & $18.60 \pm 4.02$ & $0.001^{*}$ \\
Range & $15.0-35.0$ & $10.0-25.0$ & \\
\hline
\end{tabular}

Table (6): Post-operative complications.

\begin{tabular}{lccccc}
\hline & \multicolumn{2}{c}{$\begin{array}{c}\text { Group I } \\
(\mathrm{n}=20)\end{array}$} & & \multicolumn{2}{c}{$\begin{array}{c}\text { Group II } \\
(\mathrm{n}=20)\end{array}$} \\
\cline { 2 - 3 } & No. & $\%$ & & No. & $\%$ \\
\hline RLN damage: & 0 & 0.0 & & 1 & 5.0 \\
$\quad$ Left RLN injury & 1 & 5.0 & & 0 & 0.0 \\
$\quad$ Right RLN injury & 0 & 0.0 & & 0 & 0.0 \\
Symptomatic hypocalcaemia & 0 & 0.0 & & 0 & 0.0 \\
Haematoma formation & 0 & & & & \\
\hline
\end{tabular}

Days of post-operative hospitalization were the same (2 days) for all patients in both groups. The two cases of RLN injury were transient as we founded in the follow-up visits after their voice has returned normal and confirmed by indirect laryngoscopy.

\section{Discussion}

The HS is a new device that has been introduced to surgery during the last decade. It uses high frequency mechanical energy to cut and coagulate tissues at the same time. Ultrasonic coagulation achieved by the HS is similar to that of electrocau- 
tery in that the ultimate result remains a denatured protein coagulum that coapts and tamponades blood vessels. However, the mechanism by which the proteins become denatured is completely different. Both electrocautery and lasers form the coagulum by heating tissue to denature the protein. The HS denatures protein by using ultrasonic vibration to transfer mechanical energy sufficient to break tertiary hydrogen bonds [7]. At least two mechanisms exist by which the HS cuts: Cavitational fragmentation and mechanical cutting. This sealing ability was essentially inferior to that of the other systems. However, the HS showed a smaller area of lateral thermal damage compared to the bipolar cautery [8].

The HS was originally developed for its applications in laparoscopic abdominal surgery but has found a successful application into otolaryngology specialty [9]. Unlike the variable results described with the use of the HS in tonsillectomy, literature is consistent concerning the usefulness of the harmonic scalpel in thyroid surgery. Operative times are consistently lower, bleeding is insignificant, and the resulting cost containment is evident. In our study we showed it is possible to shorten operative time by using HS. Statistical analysis showed operative time was shorter in operations where a HS was used to seal the small vessels of the thyroid gland. Thermal damage is limited to $0-2 \mathrm{~mm}$ beyond the tissue grasped within the forceps of the device and the last generation of the HS (harmonic focus) is even more appropriate since it is approved for closing vessels up to $5 \mathrm{~mm}$ in diameter [10]

Similarly, in our study we found the amount of post-operative drainage in patients treated with harmonic scalpel was reduced with respect to the other group. The reduction in intraoperative bleeding allows a more precise control of small vessels, which contributes to the reduction in post-operative drainage.

Some surgeons preferred not to place drains in cases with low intraoperative bleeding; the number of these cases was higher in the HS group $[\mathbf{8 , 1 1 , 1 2 ]}$ In our study we used a closed suction drain system to assess the post-operative drainage volume.

Our results seem to support the hypothesis that the reduced tissue injury resulting from less heat generated by the HS might lead to a reduced risk of impaired vascularity in the parathyroids glands since there is no hypocalcaemia in our studied patients and the RLN injury was the same (one patient) in each group.
In the literature, the post-operative pain has been rarely examined. The pain intensity at the surgical site was reported in three trials. While a study of Cordón et al., showed no statistical significance between the HS and conventional group [13], the trials of Defechereux et al., and Miccoli et al., demonstrated significant differences between the two groups regarding the Visual Analogue Scale (VAS) pain assessment and the mean consumption of analgesics $[8,14]$. A possible explanation is that the HS causes reduced tissue injury, with no neuromuscular stimulation, as would be induced by electrocautery.

In our study we found that the difference between the 2 groups concerning post operative pain and analgesics needed was statistically insignificant.

A major criticism to HS comes from its cost: it is disposable and expensive. The contract price for the disposable items and generator vary across different health authorities [15,16].

\section{Conflicts of interest:}

No conflict of interest has been declared.

\section{References}

1- LAYCOCK W.S., TRUS T.L. and HUNTER J.G.: New technology for the division of short gastric vessels during laparoscopic Nissen fundoplication: A prospective randomized trial. Surg. Endoscopic., 10: 71-3, 1996.

2- SIPERSTEIN A.E., BERBER E. and MORKOYUN E.: The use of the harmonic scalpel vs conventional knot tying for vessel ligation in thyroid surgery. Arch. Surg., 137 (2): 137-42, 2002.

3- HIRAM C. and WILLIAM G.: Principles of operative surgery. In: Townsend S, ed., Sabiston Textbook of Surgery, 16th ed, W.B. Saunders company, 163-8, 2001.

4- AMARAL J.F.: The experimental development of an ultrasonically activated o scalpel for laparoscopic use. Surg. Laparosc. Endosc., 4: 92-9, 1994.

5- SHEMEN L.: Thyroidectomy using harmonic scalpel: Analysis of 105 consecutive cases. Otolaryngol. Head Neck. Surg., Oct., 127 (4): 284-7, 2002.

6- LOMBARDI C.P., RAFFAELLI M., CICCHETTI A., et al.: The use of "harmonic scalpel" versus "knot tying" for conventional "open" thyroidectomy: Results of a prospective randomized study. Langenbecks Arch. Surg., 393: 627-31, 2008 .

7- McCARUS S.D.: Physiologic mechanism of the ultrasonically activated scalpel. J. Am. Assoc. Gynecol. I, apctrosc., 3: 601-8, 1996.

8- J. LANDMAN, K. KERBL, J. REHMAN, et al.: "Evaluation of a vessel sealing system, bipolar electrosurgery, harmonic scalpel, titanium clips, endoscopic gastrointestinal anastomosis vascular staples and sutures for arterial and venous ligation in a porcine model," Journal of Urology, Vol. 169, No. 2, pp. 697-700, 2003. 
9- B.J. WIATRAK and J.P. WILLGING: "Harmonic scalpel for tonsillectomy," Laryngoscope, Vol. 112, No. 8, pp. 14-6, 2002.

10- H. MARKOGIANNAKIS, P.B. KEKIS, N. MEMOS, et al.: "Thyroid surgery with the new harmonic scalpel: A prospective randomized study," Surgery, Vol. 149, No. 3, pp. 411-5, 2011.

11- PRGOMET D., JANJANIN S., BILIC’ M., et al.: A prospective observational study of 363 cases operated with three different harmonic scalpels. Eur. Arch. Otorhinolaryngol., 266: 1965-70, 2009.

12- DOCIMO G., RUGGIERO R., GUBITOSI A., et al.: Ultrasound scalpel in thyroidectomy. Prospective randomized study. Ann. Ital. Chir., 83: 491-6, 2012.

13- C. CORDÓN, R. FAJARDO, J. RAMÍREZ and M.F. HERRERA: “A randomized, prospective, parallel group study comparing the Harmonic Scalpel to electrocautery in thyroidectomy," Surgery, Vol. 137, No. 3, pp. 337-41, 2005.

14- T. DEFECHEREUX, F. RINKEN, S. MAWEJA, E. HAMOIR and M. MEURISSE: "Evaluation of the ultrasonic dissector in thyroid surgery. A prospective randomised study," Acta Chirurgica Belgica, Vol. 103, No. 3, pp. 2747, 2003.

15- MICCOLI P., MATERAZZI G., MICCOLI M., FRUSTACI G., FOSSO A. and BERTI P.: Evaluation of a new ultrasonic device in thyroid surgery: Comparative randomized study. Am. J. Surg., 199: 736-40, 2010.

16- F. SEBAG, C. FORTANIER, G. IPPOLITO, A. LAGIER, P. AUQUIER, and J.F. HENRY: "Harmonic scalpel in multinodular goiter surgery: Impact on surgery and cost analysis," Journal of Laparoendoscopic and Advanced Surgical Techniques, Vol. 19, No. 2, pp. 171-4, 2009.

\section{إستخدام مشرط الهوجات الفوق صوتية الفئية

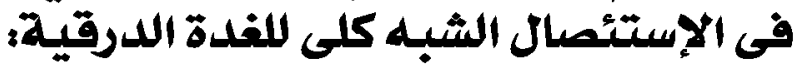 خبرة مركزواحد}

إستئصال الغدة الدرقية تعتبر من العمليات الجراحية الآكثر شيقعا ولذا آجريت وتجرى العديد من الآبحاث لدراستها وتقييم الحلول الجراحية لإستئصال الغدة الدرقية بآقل عدد من المضاعفات. وقد ظهر في العقد الآخير العديد من الطرق والبدائل الجراحية لتحسين آمان

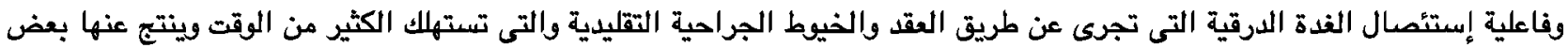

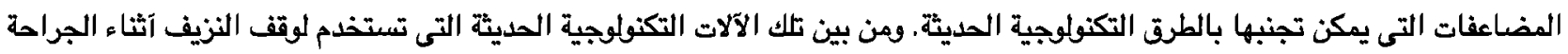
يستخدم مشرط الموجات الفوق هوتية لقطع وتخثير الآنسجة وققف النزيف فى نفس الوقت ولذا يعتبر من التكنولوجيا الواعدة لتطود العديد

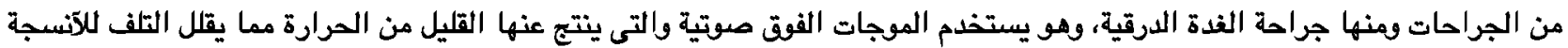

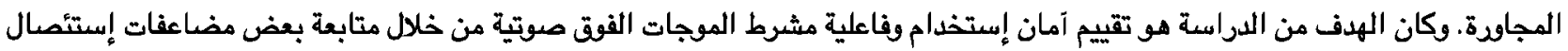

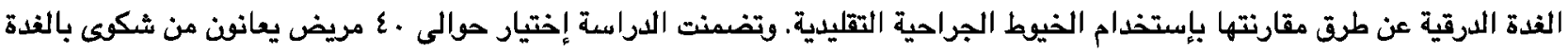

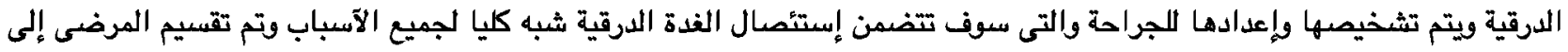

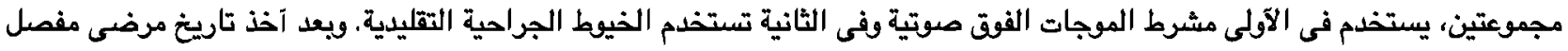

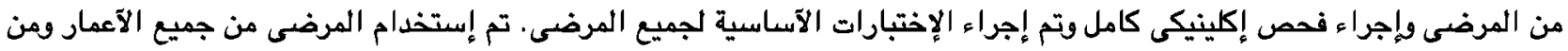

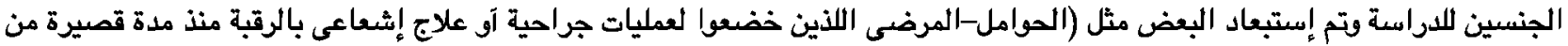

لديه أمراض بالغده الجاردرقية-المرضى الرافضين لإجراء عمليات جراحية. زيادة هرمونات الغدة الدرقية آو غدة درقية عملاقة).

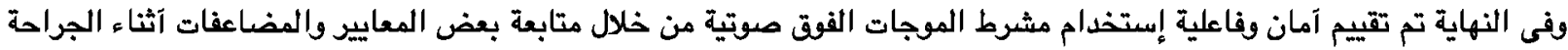

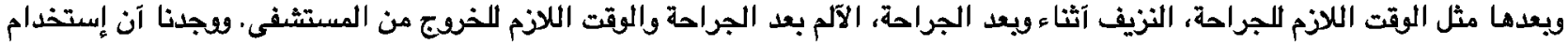

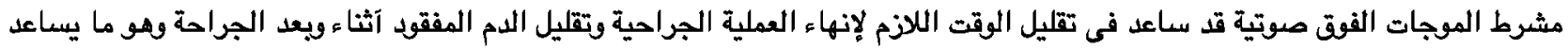

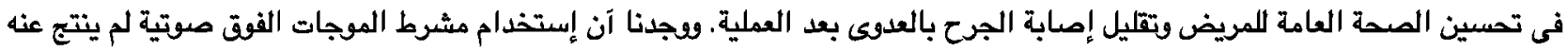

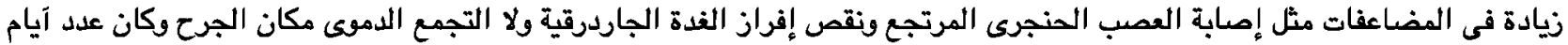

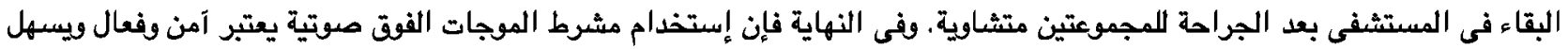
بعض الخطوات الجراحية دون آى زيادة فى المضاعفات. 